\title{
A Comparative Study of The Internal Audit System Between China and The Gulf Cooperation Council Countries
}

\author{
Saddam A. Hazaea ${ }^{1,3}$, Jinyu Zhu ${ }^{1}$, Saleh F. A. Khatib' ${ }^{2}$, Muhammad Arshad ${ }^{1}$ \\ ${ }^{1}$ School of Accounting, Yunnan University of Finance and Economics, Kunming,650221, \\ China; \\ ${ }^{2}$ Aziman Hashim International Business School, University Teknologi Malaysia, Johor, 81310 \\ Malaysia \\ ${ }^{3}$ Department of Accounting, College of Administrative and Human Sciences, Al-Jazeera \\ University, Ibb, Yemen \\ ${ }^{1}$ Email address: sadhi792@gmail.com
}

\begin{abstract}
The purpose of this comparative study is to clarify the fundamental differences of the internal auditing system in China and the Gulf Cooperation Council (GCC) countries. The literature review revealed several dissimilarities between the two regions. We discussed the development of the audit system in each context, the observance of international standards, its importance at present, and the challenges faced. Our results show that there is a vast difference between the internal audit system in china and GCC countries. Moreover, this study also provides some suggestions to address the challenges that weaken the implementation of effective internal auditing systems in these countries. This study is beneficial for academicians, policymakers, government agencies and the management of internal audit institutions in China and GCC countries.
\end{abstract}

Keywords: internal audit system, standards of auditing, internal audit structure, China, GCC

This is an open access article under the CC-BY-NC license.

\section{INTRODUCTION}

The significant development witnessed by institutions over time, as well as the growth in the field of economic relations and the expansion of the scope of trade exchanges and their overlap, made the institutions deal with several different parties and bodies with interests directly or indirectly in the institutions, which necessitated her to adopt a new job within her organizational structure, which can allow informing all these clients of all developments within the institutions, as well as the activities that she undertakes. To fully accomplish this task, this task must have impartiality and objectivity in communicating the various reports to those who are interested in this matter. On this basis, the review arose to help institutions meet these requirements. The primary objective of the audit is to preserve the property of public or private institutions by evaluating and monitoring those in charge of the state's resources from its executive and operational powers. The Chinese government started its orientation towards economic reform at the beginning of the year 1980, that is, around 30 years after 
the founding of the People's Republic of China. Where China started the processes of economic reform, economic development, and orientation towards the outside world by adopting the so-called (open door policy) (Yang et al., 2008). The Chinese government has worked to guide the use of government auditing, or the so-called (Chinese national audit), which had been replaced by other monitoring mechanisms in the 1950s (Hao, 1999). The introduction of the economic reform processes in 1980 has promoted the use internal audit systems by privet and public institutions which means that there is a beginning of awareness among the institutions of the importance of internal audit as a primary function in financial aspects which leads to the success of institutions (Li, 2008). Because of the rapid development and economic growth achieved by China in the market, there was a significant development of the internal audit function in institutions. Moreover, the application of policies set by the Chinese government in the economic aspects contributed to the development of the internal audit function (Jianwua, 1997). In recent years, the Chinese government has worked to introduce many reforms that have contributed significantly to the development of the auditing profession. These changes include independence in the manager's system, as well as the establishment of audit committees. Consequently, strengthening corporate governance as well as support for improvements in the stock market (Lin et al., 2008). In recent years, China has sought to absorb international accounting standards, including auditing standards, in addition to its endeavor to resettle global companies (Macve, 2020).

In the Gulf Cooperation Council countries, the interest in auditing has triggered by the increased demand for oil in 1974-1976, which accompanied by higher oil prices, an increase in the national income of these countries, and a significant increase in the governments' spending. As a result, regulator bodies were enlightened in setting an effective auditing system and strengthening governance laws to increase confidence in financial markets as well as to maintain efficient and sustainable growth in the corporate sector to protect the interest of the shareholders and attract foreign investments. For instance, several conferences organized by King Saud University were held (Kingdom of Saudi Arabia) in the year 1982-1983 it aimed to discuss issues related to accounting and auditing and how to develop the auditing profession to keep pace with the expansion of trade exchanges (Al- Shetwi,2011).

\subsection{Effectiveness of internal audit}

Internal audit is defined as an independent position within institutions based on examining and assessing the material and non-material aspects within the institutions and providing advice and guidance to the administration (Jihad, 2019). According to the Institute of Internal Auditors (IIA), internal audit should include the following processes: (1) Work to add value to the institutions as a consultative, objective and strategic guarantee (2) Helping institutions achieve their goals; and (3) Improving and evaluating the effectiveness of risk management. On the other hand, the internal audit system should have several characteristics such as independence, objectivity, and reducing risks and providing advisory services. The independence of the internal audit department can be achieved when the internal auditors perform their work without any interference from any party, given that independence is the most critical factor in making the effectiveness of the internal audit system (IIA, 2008). For auditors also to perform their functions as required of them, they should have adequate financial and accounting expertise (Mulugeta, 2008). Additionally, auditors need to follow a clear and precise criterion that increases the effectiveness of the internal audit system (Al-Twaijry et al., 2003). The use of the governance system is one of the most critical factors that contribute to the effectiveness of the internal audit system (IIA, 2006). 


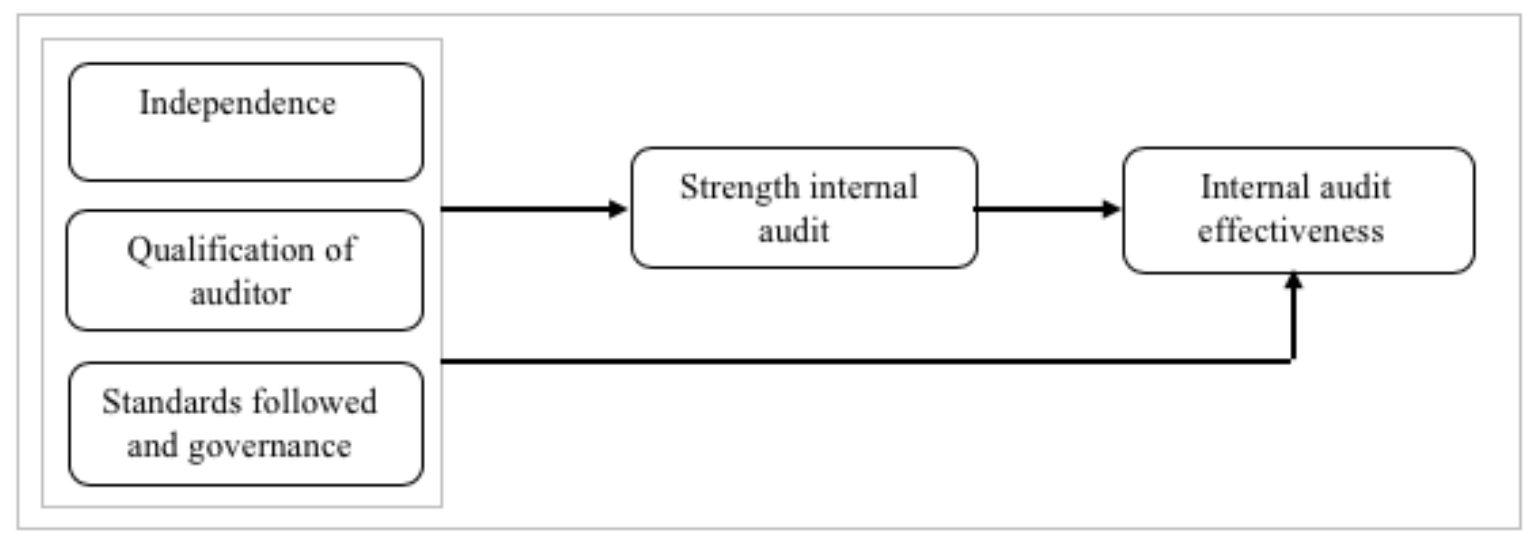

Fig. 1 Internal audit effectiveness

\subsection{Research questions}

1. Is there a difference between China and the Gulf Cooperation Council countries regarding the internal audit system?

2. What are the factors that affect the work of the internal audit system?

3. What is the level of the internal audit system in both China and the Gulf Cooperation Council countries?

\section{LITERATURE REVIEW}

The internal audit is currently viewed away from the traditional functions as one of the main pillars for improving and protecting institutions. The concept of internal auditing differs between countries due to many reasons, including economic development, the system of government followed in the country as well as the quality of the audit concepts followed in these countries. Following, we discuss the difference in internal audits between china and (GCC) countries.

\subsection{Development of internal audit}

In 1983, many instructions and principles related to the audit work were put before the State Council for approval by the National Audit Office, including the necessity of conducting audit work through the establishment of their departments in institutions. In the year 1987, the Institute of Chinese Internal Auditors was established and, in the same year, joined the Institute of internal audit (IIA) (Li, 2008). The State Council issued the auditing standards in the year 1988, which stipulated the necessity of establishing individual units for internal auditing in all institutions besides organizing the relationship between internal auditing and the rest of the departments, which contributed to the clarification of the internal audit rules and processes. In the year 1994-1995, the Chinese government issued the law of auditing and regulations related to internal auditing, respectively, which also helped in identifying the rules and processes of internal auditing $(\mathrm{Li}, 2008)$. On the other hand, in GCC, we see that the development of the auditing profession started in the year 1974 as a result of the increased demand for oil. In 1984, committees were established that were charged with preparing auditing standards in line with the rules of international auditing. After that, the Saudi Organization for Certified Public Accountants (SOCPA) was established in 1992 (Al-Twaijry, 2003).

\subsection{Challenges facing internal audit}

According to Yang et al. (2008), the current audit in China lacks complete independence and transparency, which affects the reliability of the reports. One of the challenges encounters in the 
auditing profession in China is the relative ambiguity of the audit guidelines and instructions in many aspects, especially concerning the responsibilities of auditors and management in detecting corruption. In addition to that, a change must be made by keeping pace with the updates in the international audit (Chong, 2008). In the Gulf countries, however, among the challenges facing the internal audit system is the natural ownership of companies and institutions, most of which are owned by the ruling families or families that have a relationship with the ruling families, which contributes significantly to the poor performance of internal audit (Al-Shetwi, 2011).

\subsection{Level of internal audit}

Three factors led to the high level of auditing in China and its improvement. First, the Chinese government in 2002 and 2005 implemented legal reforms that resulted in a significant increase in the statutory duties of auditors (Firth et al., 2012). Second, syndicated regulatory oversight of audit firms by the Ministry of Finance and the Chinese Institute of Certified Public Accountants (CICPA). Third, the bad reputation that the auditors have with them when they are related to the audit scandals (He et al., 2013). In the Gulf countries, the contribution of the internal audit functions to achieving the required goals is weak to some extent due to the ineffective practice of corporate governance (AlShetwi, 2011). Indeed, there are many other problems have been put forward in the literature that the internal audit system encounter in Gulf countries such as lack of full knowledge of international standards by a large sector of auditors, the lack of auditors who have extensive experience regarding auditing operations following international standards, and the nature of the culture that compels them to follow legislative instructions regarding some services (Almansour, 2019). Audit in China went through several stages, the most important of which was the first stage, which was aimed at controlling revenues and expenditures in addition to auditing the accounts related to the government budget. In the recent period, China has started to use auditing as a tool to evaluate performance in institutions, which has improved government performance and public accountability (Funkhouser and $\mathrm{Pu}, 2019$ ).

\subsection{International standards}

In China, the firms do not follow international standards, but they follow Chinese standards that closely resemble international standards in several vital parts. Meanwhile, these firms have recently worked on adopting international standards with a few modifications in line with the characteristics of the Chinese business environments. On the other side, there is a little difference between Chinese standards and international standards, especially about the concept of independence (independence of auditors) and the method that is followed to assess and examine the professional competence of auditors. Furthermore, the open-door policy adopted by China in 1980, it has become necessary to develop auditing standards in China in line with the progress that has occurred in international standards to improve the audit work and its quality (lin and Chan, 2000). In most of the Gulf countries, however, they follow the international standards except for what relates to the Islamic sector (the benefits that are imposed in the case of dealing with loans), international standards are not followed in the Islamic sector, but Sharia is followed (Hussain, 2002).

\section{RESEARCH METHODOLOGY}

\subsection{Research design}

This study relies on the deductive approach to accomplish it and achieve its goals about the theoretical aspect. We collected information on the essential elements through what was mentioned in many of the available literature that discussed this topic, such as scientific papers, periodicals and reports, doctorates dissertations and master's thesis as well as books. 


\section{FINDING AND DISCUSSION}

According to what we discussed in the comparative study above, we reached several results. There are significant differences between the internal audit system used in China compared to the internal audit system used in the Gulf Cooperation Council countries. We can highlight the following points: Regarding historical development, it can be seen that the adoption of an open-door policy and economic development is the reason for the evolution of the internal audit system in China.

But in the Gulf Cooperation Council, the increase in demand for oil and the rise in prices is the reason for the evolvement of the internal audit system. In terms of compliance with the international standards, we found that China does not mostly follow international standards but rather follows the Chinese national standards, taking into account international standards for verification only. While in the Gulf Cooperation Council countries, it follows international standards for auditing except for Islamic aspects, most institutions dealing with Islamic transactions follow the principles of Islamic Sharia. As for the factors affect the internal audit system, the authority systems have a significant impact on the performance of the audit in China, which contributed significantly to the lack of independence, as well as the lack of clear legislation to define the tasks of the internal auditors. On the other side, we also see that the most significant obstacles that the system of internal audit in the countries of the Gulf Cooperation Council faces governance systems, which are (property) and not democratic. Hence, the dominance of family ownership has limited the effectiveness, independence, and transparency of the internal audit system. In addition, the lack of training for auditors, and the scarcity of auditors who have professional experience in most of the GCC countries. The Chinese internal audit system is more effective compared to the internal audit system used in the countries of the Cooperation Council, as evidenced by the economic development and the adoption of an open policy in trading with different countries around the globe. Additionally, in the recent period, China has started to use auditing as a tool to evaluate performance in institutions, which has improved government performance and public accountability. Finally, we can say that the audit in China continues to develop rapidly, including completing improvements in corporate governance and accepting the responsibility of potential auditing as well as continuing to support the independence of the audit, and this distinguishes it from the use of auditing in the GCC countries, which we can say the development is slow and does not keep pace with changes in Commercial market.

\section{CONCLUSION AND FURTHER RESEARCH}

Based on the results obtained from the previous discussion, some recommendations are drawn in order to improve the internal audit systems significantly in both China and the Arab Gulf Cooperation Council namely: (i) enhance the independence of internal audit: to enhance the freedom of the internal review, administrative units must be created independent of the executive and operational lines and other authorities so that these departments can give a neutral (independent) technical opinion and take decisions on how to tackle the problems and this is consistent with the overall goal of the audit, which states that the auditor aims to give a neutral technical opinion about the fairness of the financial statements Li, (2008) confirms that; (ii) working to improve the quality of auditors professions through continuous training that keeps pace with updates on international standards; (iii) the work to expand the internal audit function to include current jobs without limiting the primary task in discovering fraud and moving towards achieving value for institutions, and consequently provide professional services. From the simple job, which is (discovering fraud) to the most essential job in enhancing the economy. According to the recommendations made by Li (2008), which recommended that China should change the internal audit function from the simple to the most 
critical job in grownup the economy; and (iv) the use of modern technology should be promoted, as well as greater openness to international standards.

Our research study is limited to comparing the internal audit system in both the countries of the Gulf Cooperation Council and China with reliance on previous studies and research conducted on some points.

It is recommended to conduct future studies based on practical data during recent years so that those interested can know the aspects of the differences and similarity more in addition to the possible expansion further based on a study the legal system of internal audit and internal audit institutions, main functions of internal audit, main areas of internal audit and internal audit technology.

\section{REFERENCES}

Al-Twaijry, A. A., Brierley, J. A., and Gwilliam, D. R. (2003) 'The development of internal audit in Saudi Arabia: an institutional theory perspective', Critical Perspectives on Accounting, Vol.14, No.5, PP. 507-531.

Al-Shetwi, M., Ramadili, S. M., Chowdury, T. H. S., and Sori, Z. M. (2011) 'Impact of internal audit function (IAF) on financial reporting quality (FRQ): evidence from Saudi Arabia,' African Journal of business management, Vol. 5, No. 27, PP. 11189-11198.

Almansour, M. S. (2019) 'Challenges and opportunities from adopting IFRS in Saudi Arabia: the case of the banking sector (Doctoral dissertation, Nottingham Trent University).

Chong, H. G. (2008) 'Auditing in China, 'Journal of Corporate Accounting and Finance, Vol.19, No.6,PP. 49-54.

Firth, M., Mo, P. L., and Wong, R. M. (2012) 'Auditors' organizational form, legal liability, and reporting conservatism: Evidence from China, Contemporary Accounting Research, Vol. 29, No.1, PP. 57-93.

Funkhouser and $\mathrm{Pu},(2019)$ 'Government performance auditing in the US and China: lessons drawn from comparative review, Chinese Public Administration Review, Vol. 10, No.2, PP 65-78.

He, X., Pittman, J., Rui, O.M., (2013) 'Reputational implications for partners after a major audit failure: evidence from China, Journal of Business Ethics, Vol. 138, No.4, PP. 703-722.

Hao, Z. (1999) 'Regulation and organization of accountants in China; Accounting, Auditing an Accountability Journal, Vol. 12, PP. 286-302.

Hussain, M., Islam, M. M., Gunasekaran, A., and Maskooki, K. (2002) 'Accounting standards and practices of financial institutions in GCC countries. Managerial Auditing Journal, Vol. 17, No.7, PP. 350-362. doi:10.1108/02686900210437453.

IIA (2006) 'The role of auditing in public sector governance. Altamonte springs, FL: The Institute of Auditors Research Foundation.

IIA (2008) 'International Standards for the Professional Practice of Internal Auditing. Altamonte Springs, FL: The Institute of Internal Auditors Research Foundation.

IIA (2012) ' International standards for the professional practice of internal auditing (Standards), available://www.iia.org.au/technicalResources/knowledgeitem.aspx?ID=256.

Jihad, N (2019) 'Recent trends of internal audit and its role in supporting competitive advantage, a thesis submitted for fulfillment of the Master's degree of the philosophy of accounting, Sudan University of Science and Technology, Sudan.

Jou, Jianwua (1997) 'The present situation and developing trends of Chinese internal auditing," Managerial Journal, Vo.12. No.4/5. PP.235-242. 
Lin, K. Z., and Chan, K. H. (2000) 'Auditing standards in China-a comparative analysis with relevant international standards and guidelines, The International Journal of Accounting. Vol.35, No.4, PP. 559-577.

Lin, Z. J., Xiao, J. Z., and Tang, Q. (2008) 'The roles, responsibilities, and characteristics of the audit committee in China. Accounting, Auditing and Accountability Journal. Vol.21, No.5, PP.721751. Doi:10.1108/09513570810872987.

Li, Y. (2008). A comparative study about internal auditing approach between Germany and China. Chengdu City, China: Southwestern University of Finance and Economics, October, 7.

Macve, R. (2020) 'Perspectives from mainland China, Hong Kong and the UK on the development of China's auditing firms: implications and a research agenda, Accounting and Business Research, 1-52.DOI:10.1080/00014788.2020.1736494.

Mulugeta, S. (2008) 'Internal audit: reporting relationship in Ethiopian public enterprises. M.Sc. Dissertation. Ethiopia: Addis Ababa University. available online at: http://etd.aau.edu.et/dspace/bitstream/123456789/1966/1/Samuel\%20Mulugeta.pdf.

Yang, S., Xiao, J. Z., and Pendlebury, M. (2008) 'Government auditing in China: Problems and reform, Advances in Accounting, Vol. 24, N,1, PP. 119-127. 